\title{
Historia de dos industrias: un debate en torno a la historieta argentina y española
}

\section{Amadeo Gandolfo, Pablo Turnes y Gerardo Vilches}

Amadeo Gandolfo (1984) es licenciado en Historia y doctor en Ciencias Sociales. Realizó su doctorado como becario del Consejo Nacional de Investigaciones Científicas y Técnicas (CONICET) y actualmente es becario posdoctoral por la misma institución. Se desempeña como Jefe de Trabajos Prácticos en la materia «El Lado B de la Sociología: nuevas sociologías pragmático-pragmatistas y su reencuentro con viejas tradiciones», optativa de la Carrera de Sociología de la Universidad de Buenos Aires. Fue miembro organizador del Congreso Internacional Viñetas Serias en su más reciente edición (2014). Participa en el Área de Narrativas Dibujadas de la Carrera de Comunicación en la UBA, bajo la dirección de Laura Vazquez. Brinda talleres de crítica de historieta junto a Pablo Turnes con quien edita la revista de crítica de historietas Kamandi. Escribe y mantiene el blog El Baile Moderno desde el año 2007. Publicó en Crisis, Los Inrockuptibles, Mancilla, Haciendo Cine y otros medios. Asimismo, ha publicado en revistas y libros de carácter académico de Argentina, Brasil, Bélgica y Estados Unidos.

Pablo Turnes es profesor en Historia por la Universidad Nacional de Mar del Plata, magíster en Historia del Arte argentino y latinoamericano por el Instituto de Altos Estudios Sociales - Universidad Nacional de San Martín y doctor en Ciencias Sociales por la Universidad de Buenos Aires. Realizó su doctorado como becario del Consejo Nacional de Investigaciones Científicas y Técnicas (CONICET) y actualmente es becario posdoctoral por la misma institución. Se desempeña como Jefe de Trabajos Prácticos de la cátedra Historia de los medios de comunicación nacional y latinoamericana, en la Universidad Nacional de Moreno. Fue miembro organizador del Congreso Internacional Viñetas Serias en sus tres ediciones (2010, 2012 y 2014). Participa en el Área de Narrativas Dibujadas de la carrera de Comunicación en la UBA, bajo la dirección de Laura Vázquez. Brinda talleres de crítica de historieta junto a Amadeo Gandolfo, con quien además co-edita la revista web Kamandi. Ha participado de diferentes compilaciones y ha publicado numerosos artículos en revistas académicas y de divulgación. Su tesis de maestría será editada por Tren en Movimiento bajo el título El exilio de las formas. Alack Sinner de José Muñoz y Carlos Sampayo. Su tesis de doctorado se titula La excepción en la regla. La obra historietística de Alberto Breccia (1962-1993). 
Gerardo Vilches (1980) es licenciado en Historia (UCM) y máster en Métodos y técnicas de investigación (UNED). Actualmente termina su tesis doctoral sobre el proceso político de la transición española a través de las revistas satíricas. Es profesor de Didáctica de las Ciencias Sociales en la Universidad Europea de Madrid. Es autor de Breve historia del cómic (Nowtilus, 2014) y El guión de cómic (Diminuta, 2016). Codirige CuCo, Cuadernos de cómic y es parte de la organización de GRAF, un encuentro de cómic de autor y edición independiente. Ha colaborado en las antologías de ensayos Radiografías de una explosión, Hijos del átomo, El cómic digital hoy y Cómics Esenciales. Anuario 2016. Ha participado con sus textos en antologías de cómic como Panorama. La novela gráfica española hoy y Hoodoo Voodoo. Ha participado con ponencias y comunicaciones en diversos congresos, jornadas y cursos universitarios, y publicado artículos en revistas científicas como Historia del presente. Es colaborador de medios como Rockdelux, Canino, Cactus, Las calles de Venecia o Kamandi. Formó parte del blog de referencia Entrecomics entre 2011 y 2016. Mantiene su blog de crítica y análisis, The Watcher and the Tower, desde 2007.

Fecha de de recepción: 24 de abril de 2016

Fecha de aceptación definitiva: 6 de mayo de 2016 
Gerardo Vilches: Me gustaría iniciar este debate remontándonos a los orígenes de las industrias española y argentina. En el caso español, la historieta surge en la prensa, como en muchos otros estados. Se trata de viñetas de contenido político y social, satíricas, y encontramos a pioneros como Apeles Mestre, Mecachis, Xaudaró... Más adelante empiezan a incluirse historietas en publicaciones infantiles. TBO aparece en 1917, y, como sabéis, da origen al término «tebeo», aunque tarda en incluir de forma regular páginas de historieta.

Pero creo que hasta después de la Guerra Civil la industria del cómic español no arranca definitivamente, con Bruguera — antes El Gato Negro - como dominadora del mercado y Editorial Valenciana o Toray como principales competidoras.

El contexto de la posguerra sería fundamental para entender cómo se configura el mercado, porque si los tebeos se convierten en uno de los principales entretenimientos de la infancia española es por la dureza de la situación económica, que impedía que opciones de ocio más caras desplazaran a los tebeos, muy baratos. Para muchos niños y niñas, prácticamente eran lo único que podían permitirse adquirir, aunque fuera de segunda mano o en locales que los alquilaban más baratos aún.

En ese contexto, la producción crece durante todos los años cuarenta y cincuenta, y llena los quioscos de toneladas de revistas de historieta, al tiempo que da trabajo a multitud de profesionales que, en muchos casos, fueron anónimos. En ese contexto industrial, muchos de ellos - no todos - podían ganarse la vida dibujando, pero mi opinión es que, por un lado, lo hacían a costa de trabajar muchísimas horas, y por otro, nunca obtuvieron una parte proporcional de lo que generaban a las empresas editoriales. Y, por supuesto, estaba la cuestión de que los derechos de autor no eran reconocidos en absoluto. Ni se planteaba su reivindicación: los autores entregaban sus páginas y a partir de ese momento las editoriales disponían de los originales como querían. Los reeditaban una y otra vez sin volver a pagarlos, los manipulaban, los dejaban olvidados en un almacén... Como en otros mercados, en suma, el cómic distaba mucho de tener la consideración de arte. Era más bien un oficio más dentro del sector editorial, y los dibujantes eran obreros, no artistas.

Pablo Turnes: Sin meternos en cuestiones tales como cuándo comenzaría la historieta, con sus antecedentes decimonónicos, creo que no hay dudas que entre el fin del siglo XIX y principios del siglo xx comienza el desarrollo y la instalación definitiva de la historieta moderna. Y sí, su lugar original en Argentina fueron las tiras de prensa. 
Los norteamericanos, como el diablo, metieron la cola y comenzaron rápidamente a vender sus tiras sindicadas para la década de 1910, e incluso antes. La cosa cambió hacia fines de la década del treinta, cuando empezaron a aparecer las editoriales de revistas dedicadas exclusivamente a las historietas, como Patoruzú (de Dante Quinterno), Misterix (de Editorial Abril, proyecto de los hermanos italianos Civita), Tit Bits (del editor Manuel Láinez), etcétera. Entonces la influencia norteamericana se instaló definitivamente tanto para editores como para dibujantes: la factoría Disney y los maestros norteamericanos como Hal Foster, Alex Raymond y Milton Caniff eran los modelos a seguir.

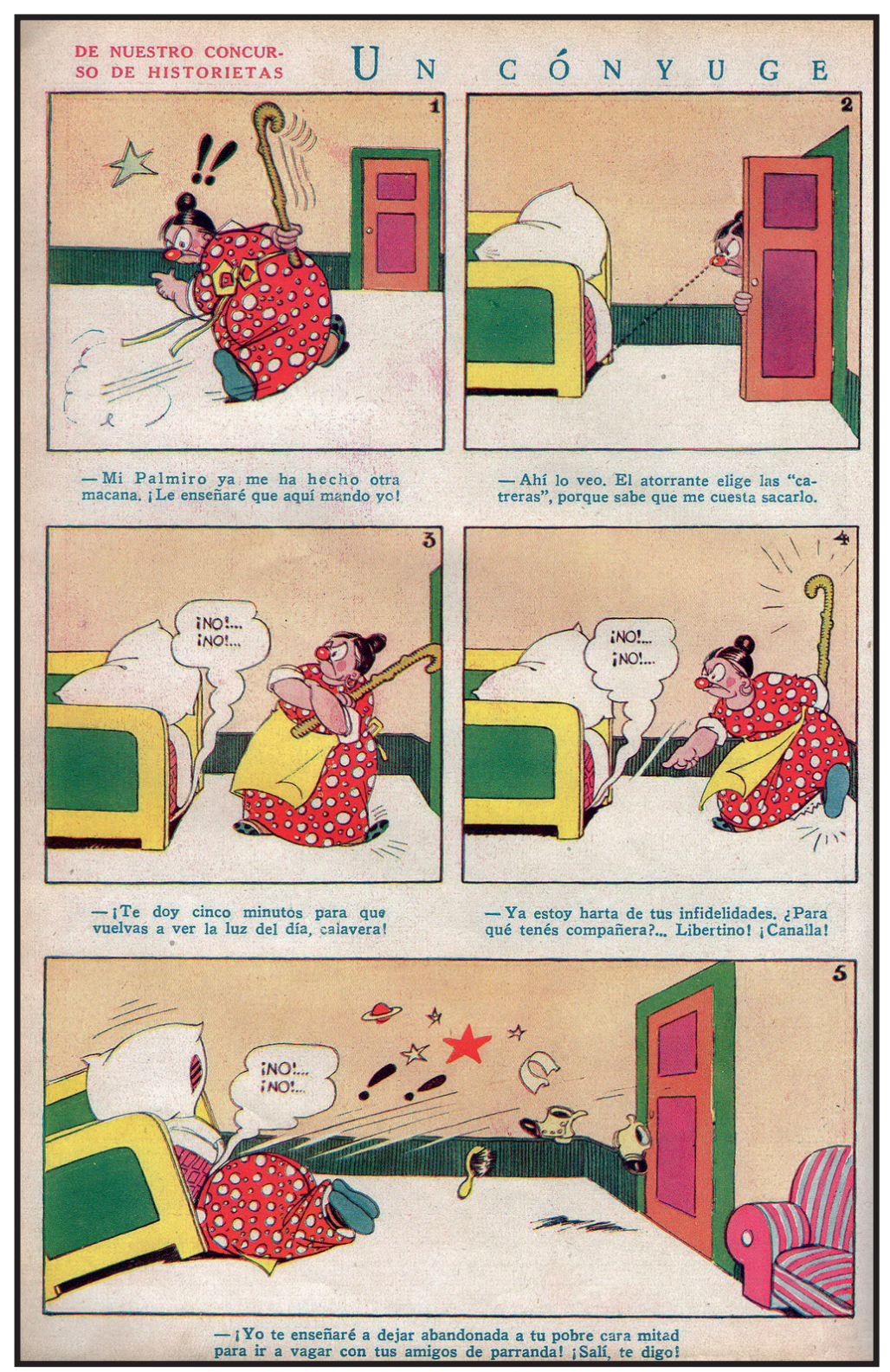

FIG. 1. Parte de la primera historieta de Dante Quinterno aparecida en Caras y Caretas, n. ${ }^{\circ}$ 1548 (2 de junio de 1928). 
Hay que notar que la entrada de los Estados Unidos al mercado del entretenimiento estuvo facilitada por cuestiones como las guerras mundiales (que redujo el tráfico transatlántico y afectó a la producción de los países europeos). Además la industria editorial local fue favorecida por la Guerra Civil española, que dejó un vacío en el mercado, porque España no podía seguir exportando material a sus antiguas colonias.

En cuanto a lo de los derechos, el sistema era básicamente el mismo, y tiene que ver con una lógica industrial: se produce para alguien, un editor, quien retiene los derechos y cambia trabajo por salario, es decir, páginas por dinero. Esto se mantuvo así en un nivel general, a excepción de la breve pero definitiva experiencia de Editorial Frontera (1957-1959), de los hermanos Oesterheld, que se planteó como una cooperativa donde los dibujantes eran socios en partes iguales, invertían para recuperar el dinero más la ganancia, y retenían sus derechos de autor.

Amadeo Gandolfo: Bueno, veo que ambos ya han recuperado el contexto histórico de una manera muy clara, así que ¿qué me queda a mí? En primer lugar señalar algunas similitudes y sincronías. Para arrancar, la idea de industria, y la idea de masividad. Es el estigma de todas las «historietas periféricas» (si entendemos como centrales a las industrias norteamericana, franco-belga y japonesa). ¿Cómo hacer para volver a esa edad dorada, cómo vender más, cómo pagar mejor, cómo sostener la actividad? Son todas preguntas que aparecen continuamente en las discusiones y proceden de este punto de partida: la España posguerra en un caso, la Argentina sustituidora de importaciones, predesarrollista, en el otro, momentos donde se vendía mucha historieta, donde se podía vivir de ella y ser un burgués «respetable» y donde la historieta tenía una notoria penetración social.

Ya la colocación histórica nos debería decir algo. Eran momentos muy particulares, en los cuales la historieta se erigía como una de las más deseables fuentes de diversión masiva. El colorido, la familiaridad con los personajes, los estilos de dibujo, la regularidad, todos estaban pensados para atraer a la mayor cantidad de personas y entretenerlas semana a semana. En segundo lugar, tiene algo que ver con la idea de proteccionismo y de nacionalismo: vivamos con lo nuestro, produzcamos nuestros propios símbolos, nuestros propios héroes, nuestras propias empresas, compitámosle a los centros de producción mundial de fantasías.

Ese tipo de actitud industrial lleva como correlato la pérdida del valor «artístico» y la lógica del trabajo, que siempre fue un elemento condenado de los albores de la historia de la historieta en análisis posteriores, pero que es la contraparte de la lógica masiva e industrial. A la vez, la altísima producción, los entrecruzamientos entre historietas nacionales y extranjeras, el caos temático y estilístico de estos primeros años, en muchos casos da lugar a obras singulares, a los resquicios entre lo estandarizado. Creo que, tanto en el caso argentino como en el español, hay mucho todavía por investigar y descubrir de estos inicios.

$\mathrm{El}$ problema es qué pasa una vez que esa lógica termina (también uno se podría preguntar cómo extenderla en el tiempo, pero en Argentina eso es hacer historia contrafáctica). En el caso argentino, eso sucede como consecuencia de un proceso muy largo y multicausal que se 


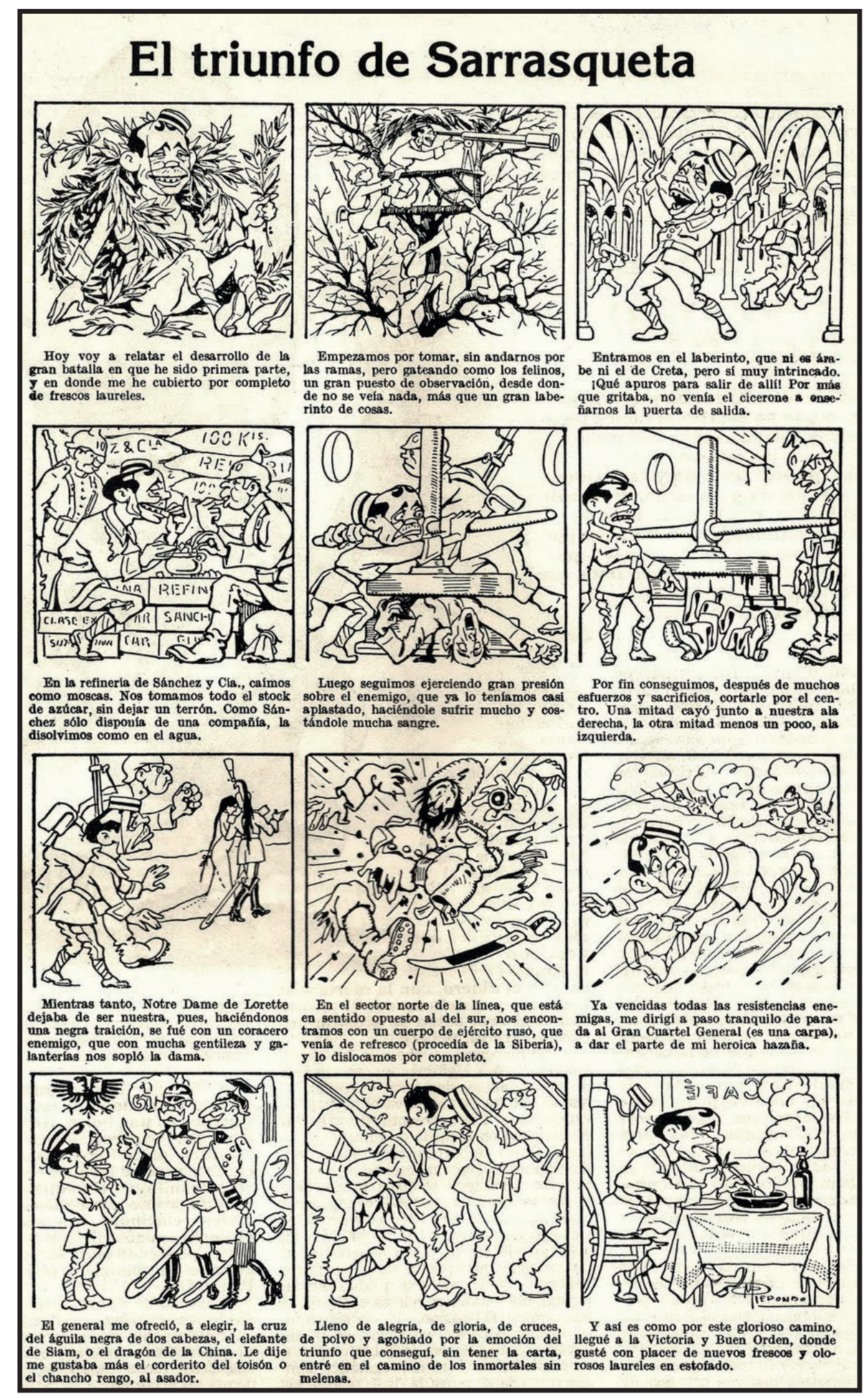

FIG. 2. Redondo, M. «Don Goyo y Sarrasqueta», en Caras y Caretas (1914). 
inicia a finales de los cincuenta y se prolonga hasta los noventa. Pareciera que desde entonces discutimos cómo volver a una industria funcional, dónde refugiarse.

Pero ese proceso también es parte de una evolución mundial que ve a la historieta desaparecer lentamente de las preferencias de entretenimiento del gran público. En algunos casos se troca comercialismo por legitimación artística, como si todo fuese un juego de suma cero y no pudieses tener a la vez una industria vital y grande y la chapa del creador. Y también genera una crisis para el propio dibujante y guionista: ¿qué hacer? Ya la promesa del trabajo estable no está.

Como digo, va a ser un proceso larguísimo, lo cual da a lugar a infinidad de respuestas posibles: dejar la actividad, amargarse, erigirse en autoridad creativa y estética, en singularidad, vender para afuera, aferrarse a lo poco que queda, pasar a la ilustración, a la animación, a la publicidad, colocarse en el lugar del editor que intenta reavivar el juego. En España no estoy tan al tanto de cómo sucedió, pero para eso estamos acá, ¿̨no?

Gerardo Vilches: Esa es la idea, al menos. Pero antes de llegar a ese punto, me resulta interesante recuperar algunas cuestiones que ambos habéis apuntado. La primera es la influencia de Estados Unidos; en España se publicaron cómics de Disney en fechas muy tempranas, y los superhéroes de DC llegaron de la mano de la editorial mexicana Novaro en los cincuenta. Siempre he tenido la sensación de que el tebeo de aventuras bebía mucho de la historieta realista norteamericana, y esto conecta con la segunda cuestión que quería recuperar: los personajes icónicos, los héroes.

La idea que señala Amadeo sobre la necesidad de héroes propios la veo muy claramente en el tebeo español, también: Capitán Trueno, el Guerrero del Antifaz, Roberto Alcázar y Pedrín... se convierten en héroes tremendamente populares. Pero me resulta muy significativo que, a pesar de que algunos de esos personajes hoy se asocian con el franquismo y sus valores, en realidad no hablaban de política y sus valores distaban de estar vinculados directamente al régimen, aunque compartieron cierto zeitgeist.

Como ha señalado Óscar Gual, una serie como Roberto Alcázar y Pedrín, que ha pasado al imaginario colectivo como un producto franquista, en realidad nunca mostró una aventura que transcurriera en España, y sus contenidos no eran muy diferentes a los que se podían encontrar en series de acción y aventura de la época en todo el globo. ${ }^{1}$ Por no mencionar que creadores como Víctor Mora — guionista de Capitán Trueno o El Jabato- y José Jordán Jover — uno de los primeros guionistas de Roberto Alcázar y Pedrin - fueron republicanos represaliados tras la Guerra Civil.

Tengo curiosidad por saber cómo eran los héroes del cómic infantil argentino de esa época, años cuarenta y cincuenta, antes de la llegada de Oesterheld. Sobre todo porque el contexto político era muy diferente al español, imagino.

${ }^{1}$ Gual Boronat, Ó. Viñetas de posguerra. Los cómics como fuente para el estudio de la historia. Valencia, Universitat de València Publicacions, 2013, pp. 67-111. 


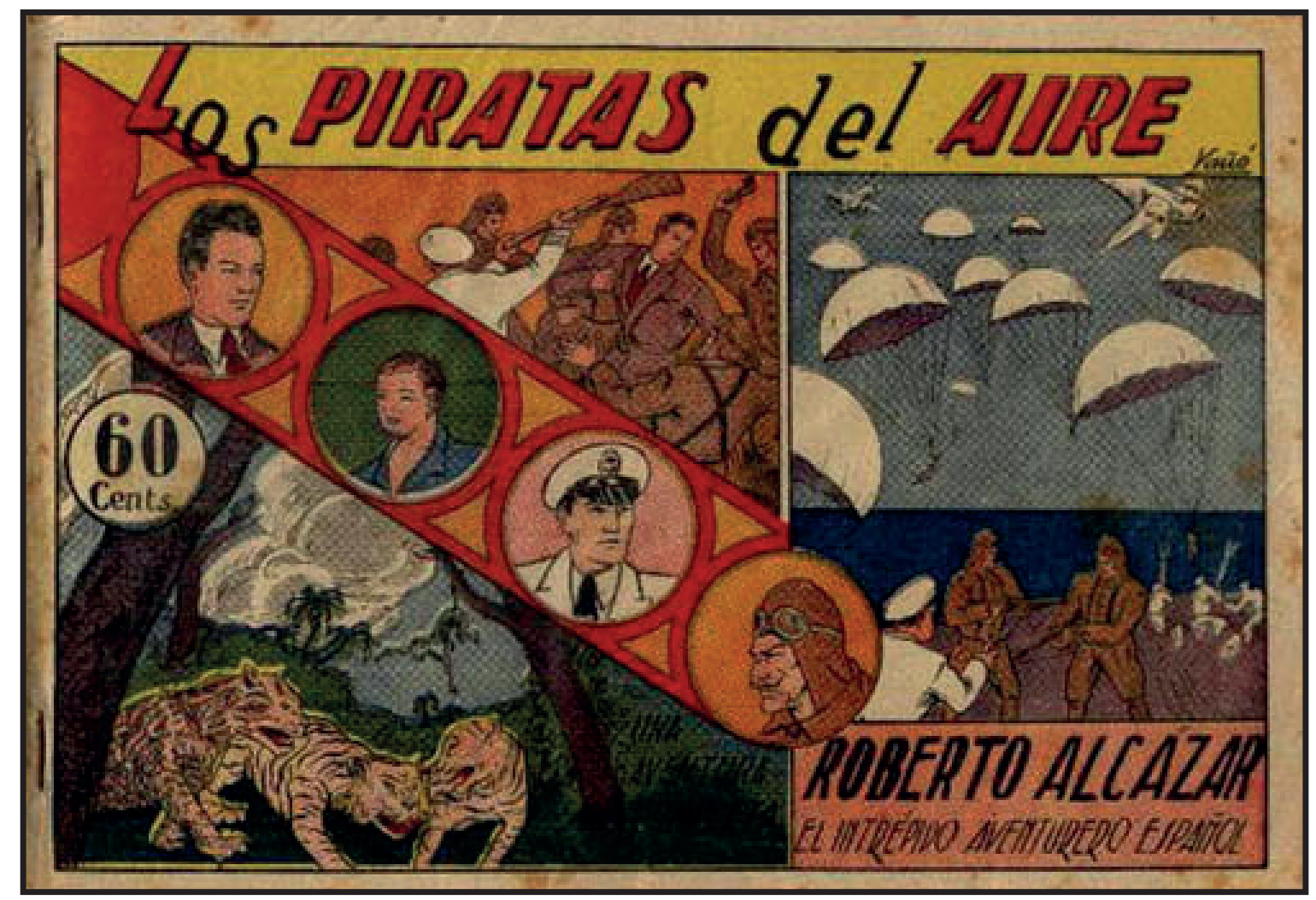

FIG. 3. Arizmendi, A. y VAño, E. Roberto Alcázar y Pedrin. Los piratas del aire. Valencia, Editorial Valenciana, 1941.

Amadeo Gandolfo: Lo que sucede en Argentina en ese período son dos cosas. Por un lado, tenemos los personajes de humor gráfico producidos por Lino Palacio, Guillermo Divito, y por la factoría Dante Quinterno. Menciono esos tres ejemplos porque son los más populares, pero en alguna medida todos los personajes humorísticos creados en ese momento seguían la misma fórmula. ¿Cuál era? Bueno, una característica inmutable alrededor de la cual se organizaba el humor, como una fórmula resorte en la que siempre sucedía más o menos lo mismo y la evolución era imposible.

Personajes como Avivato, Don Fulgencio, El Doctor Merengue, Bólido, Ramona, Pochita Morfoni, habitaban una Buenos Aires privada de todo tipo de particularidad, un barrio eterno siempre anclado en la clase media y los problemas familiares. Lo que importaba era la repetición de un esquema, las mil y una maneras de explotar una particularidad para producir el gag dentro de cada tira con elementos narrativos y gráficos que cambian muy poco.

Por otro lado, tenemos los personajes de aventuras surgidos previamente a Oesterheld. Mayoritariamente, ellos provienen de la factoría Dante Quinterno y de Editorial Columba. Especialmente en la revista Patoruzito, que comienza a editarse en 1945, cuyo objetivo era ser una gran revista de aventuras para toda la familia, y especialmente para los niños. En esa revista, por un lado, se publicaban historietas norteamericanas (Flash Gordon, Captain 
Marvel Jr. y algunas otras mucho menos conocidas, que dan la impresión que compraban sin fijarse demasiado en la calidad ni con mucho criterio editorial) y, por otro, se editaban las aventuras de Patoruzito, El Gnomo Pimentón, Langostino, Don Pascual, Rinkel el Ballenero, Vito Nervio.

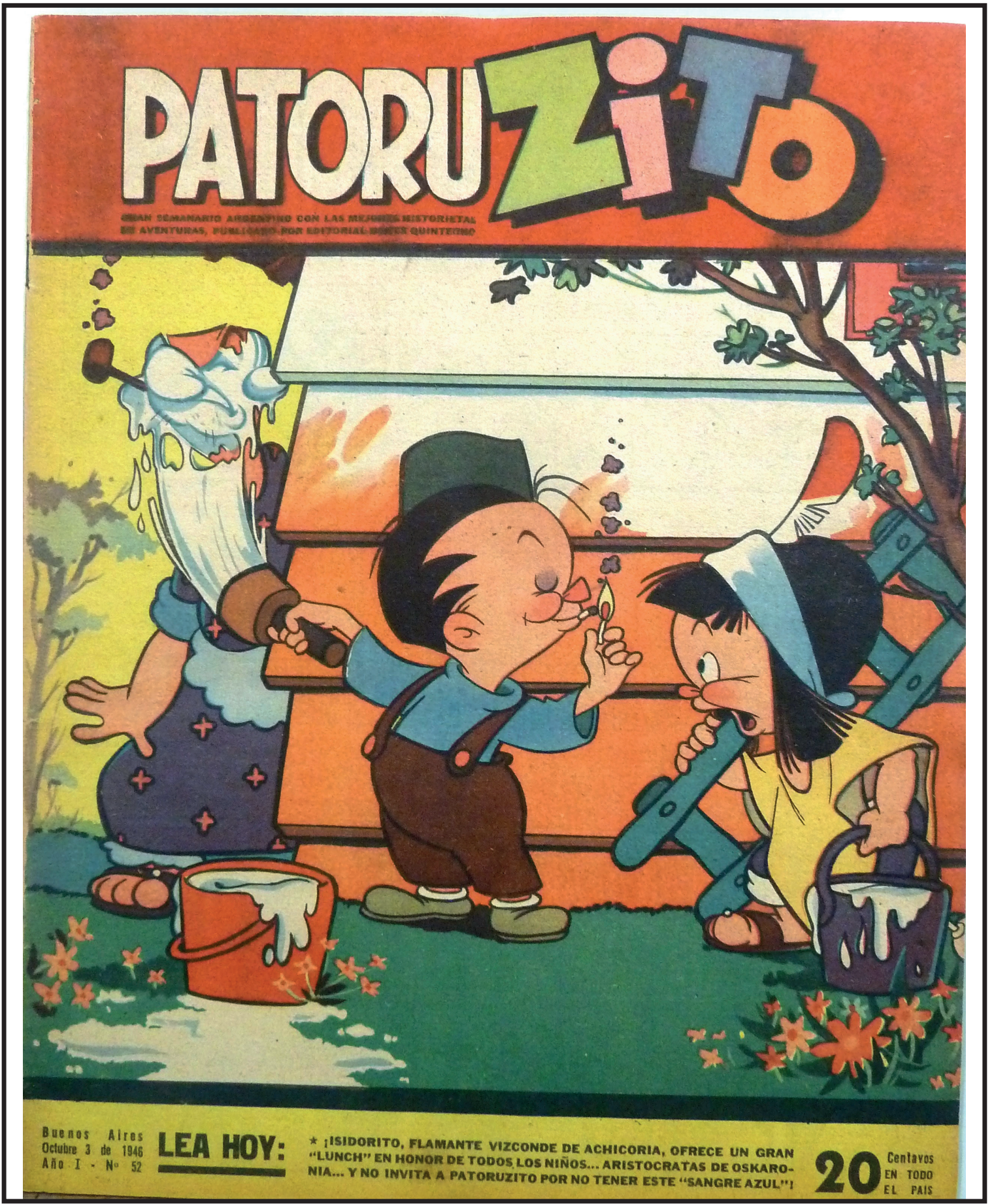

FIG. 4. Lovato, T. Patoruzito, n.o 46 (1946). 
Estas últimas, que para mí son las series más interesantes y «autóctonas» de algún modo, tenían un estilo de dibujo cercano al dibujo animado, no realista, caricaturesco, de pies grandes y colores fuertes, y aventuras que oscilaban entre territorios fantásticos (son reconocidos en ese sentido los viajes de Langostino a islas rarísimas y mundos subatómicos) y la misma Buenos Aires / Patagonia (en el caso de Patoruzito) que parece detenida en el tiempo y, sobre todo, separada de la política y lo social nacional.

Las otras (Vito Nervio, Rinkel), que para mí son un gran aburrimiento, son series de dibujo realista construidas sobre el modelo Salgari / Verne / Stevenson de aventura, que suceden en cualquier lado, ciertamente no en Buenos Aires ni en ningún lugar de la Argentina. Y que tienen como modelo a seguir al estilo preciosista, anatómicamente perfecto y pesado de José Luis Salinas en la faz gráfica.

Pero, por otro lado, en Argentina tenemos un fenómeno sumamente curioso, que es el de la historieta gauchesca. Esta hace las veces de historieta de aventuras «local», con escenarios «nacionales» y un personaje social «reconocible». Lindor Covas, Lanza Seca, Cirilo el Audaz, el Cabo Savino, son todos personajes que pretenden poner en contacto al lector con la rudeza de la vida campestre, con las vicisitudes de una historia vista de una manera edulcorada y teñida de liberalismo.

O sea, los indios raramente son protagonistas y muy escasamente heroicos pero el gaucho, que en realidad fue una figura social despreciada por las elites porteñas liberales que erigieron y controlaron el Estado Argentino y cuyo exterminio fue tan buscado como el del indio, es endiosado como la raíz de la identidad argentina por completo ficticia.

Pablo Turnes: Es interesante ese señalamiento sobre la relación industria del cómic / identidad nacional. Yo creo que hay muchas similitudes entre un país y el otro, aunque por razones bien diferentes. España estaba aislada después del fin de la Segunda Guerra Mundial, por lo cual se reforzaba la cuestión identitaria-españolista como método de control interno. En Argentina, la cuestión tuvo que ver con una industrialización acelerada desde la década de 1930 a partir de la crisis económica mundial y el alejamiento de los capitales británicos. La industria nacional tuvo que sostenerse primeramente sobre un mercado interno, y en el caso de la industria del entretenimiento, había que hablar el mismo idioma, los mismos códigos.

Evidentemente, no había una lógica exportable, como hacían los norteamericanos y en algún punto los franco-belgas: eran historias y personajes demasiado locales como para ir más allá de las fronteras (aunque en el caso argentino, las historietas se exportaban al resto de los países latinoamericanos). De hecho, durante el gobierno peronista, Argentina firmó tratados de intercambio con la España franquista que incluían productos de entretenimiento, sobre todo películas. Pero al parecer no hubo un gran intercambio de historietas, lo cual habla de esa lógica cerrada y localista.

Hablando específicamente de los personajes, todos esos nombres que citaba Amadeo eran juegos de palabras que remitían a una cierta característica moral adjetivada muchas veces a 
través del lunfardo criollo. Ser un Avivato, un Afanancio, un Bólido, una Pochita Morfoni, un Fallutelli, eran adjetivos que la gente usaba comúnmente y que se han perdido con el tiempo (pero se usaban hasta la década del sesenta, tal vez en los setenta también). Creo que había una relación íntima entre historieta, personajes y público que se perdió en ese nivel de masividad y en su entramado con la vida cotidiana de las personas.

Había una idea de «despolitización» (siempre relativa) del entretenimiento. Las cosas giraban más en torno a ciertos tipos morales / ideales de la identidad, con cierta crítica social traficada en ese esquema. Está claro que la España de Franco creó una idea de «españolidad» basada en el estereotipo del flamenco, el torero, la gente gritando «¡Olé!», etcétera. Era un esquema sostenido dictatorialmente, por lo cual era difícil romper con eso y al mismo tiempo hacer algo más contemporáneo. Los héroes españoles existían en una Edad Media o en una modernidad temprana algo vaga e idealizada, ese es el precio para escapar de la censura: la descontextualización.

En Argentina la obsesión fue siempre la misma: el arribismo, el oportunismo, el ascenso social rápido e inescrupuloso, algo esperable en un país formado a base de inmigración masiva y heterogénea, gobernado por una élite terrible y criminal, donde la vida era dura y las posibilidades de participar en una vida política y democrática eran básicamente nulas. Hay ejemplos tempranos como Don Goyo Sarrasqueta (Manuel Redondo, 1913) o El Negro Raúl (Arturo Lanteri, 1916), donde se ejerce una especie de lección moral: no intente ser más de lo que se es, ya sea uno un negro o un inmigrante español (hay que notar que muchos de estos personajes aparecían en publicaciones cuyos empresarios, caricaturistas y dibujantes eran inmigrantes españoles). Y al mismo tiempo se pueden entender filtraciones discursivas que indican lo contrario, cierta reivindicación de esa marginalidad y una crítica bastante ácida a la élite argentina.

Para las décadas del cuarenta y cincuenta, esos inmigrantes ya estaban adaptados a la vida nacional, ya tenían hijos y nietos, pero se habían congelado ciertos estereotipos (el del camarero gallego siendo el más clásico), y se hacía hincapié en esa pequeña burguesía de pasado europeo que pretendía ser más de lo que era, fuertemente basada a su vez en el estereotipo del porteño, el habitante de la ciudad de Buenos Aires.

El caso de la historieta gauchesca es muy significativo, porque está muy poco estudiado y totalmente olvidado. Sin embargo, en su momento tuvo un gran éxito, era una especie de wéstern argentino, nacido de ese género literario de fines del siglo xix, con el Martín Fierro como obra principal, mezclado con el género cinematográfico norteamericano.

Amadeo bien lo ha dicho: ante el miedo provocado por las oleadas de inmigrantes italianos, la élite argentina reaccionó con leyes represivas y policiales, pero además instalando la idea del gaucho como el icono nacional. Ese mismo gauchaje rebelde que había sido exterminado con la «guerra de policía», como propuso Bartolomé Mitre, ahora era despolitizado y puesto en el campo como en estado de naturaleza: lo puro, lo sacrificado, lo dócil, el «hombre de la tierra», por decirlo así. La historieta tuvo su papel en ese proyecto, aunque tardíamente, y habría que indagar mejor sus alcances y su discurso. 
Gerardo Vilches: Habéis mencionado temas muy interesantes respecto a la producción y los personajes tipo. Y creo, como apuntáis, que efectivamente se pueden establecer paralelismos entre los personajes argentinos y los españoles de la misma época. En cuanto a los héroes de tebeos de aventuras de estilo de dibujo más o menos realista, se cumple lo que dice Pablo: la deslocalización de las historias, que suceden en una Edad Media aún más anacrónica que la de Principe Valiente — caso de Capitán Trueno-, una Edad Antigua de idéntica naturaleza - El Jabato-, o épocas pasadas marcadas en la imaginería del franquismo como periodos dorados donde la gloria española alcanzó su máximo esplendor: el Siglo de Oro —El cachorro (Iranzo) - y la Reconquista - El guerrero del antifaz (Gago).

Sin embargo, en el humor y la sátira sí encontramos personajes apegados a la actualidad, aunque nunca se termine de concretar. Por ejemplo, vemos una predilección por ambientes urbanos, puesto que las ciudades estaban creciendo entonces gracias a la emigración del campo a las urbes, pero no aparecen apenas lugares reconocibles, no se identifica el escenario de la acción. Y me llama la atención lo que habéis contado sobre la historieta gauchesca, porque el campo, el ambiente rural, suele aparecer como un espacio, distante, hostil y atrasado, un lugar donde acudir, en algunas historietas, buscando descanso o tranquilidad, pero de manera excepcional, y donde la rudeza de sus habitantes contrasta con el civismo urbanita de los personajes humorísticos.

Hay que precisar también, sobre eso, que el tipo de personaje que abunda en las primeras décadas de la posguerra en las historietas de humor de la editorial Bruguera es el de un perdedor, alguien a quien le suceden desgracias con fines humorísticos. Se incide en la mala suerte, la predestinación y el castigo sistemático, ya se sea un tipo moral positivo o negativo, como si se huyera deliberadamente de la moraleja para entregarse al humor negro y anárquico.

Los personajes responden a estereotipos y tipos sociales de la época: la familia de clase media - La familia Ulises de Benejam-, la criada - Petra de Escobar-, las solteronas - Las hermanas Gilda de Vázquez-, el pobre - Carpanta de Escobar-, etcétera. El fenómeno que comenta Pablo, según el cual los personajes de historieta se convertían en adjetivos usados en la calle, también se dio en España, aunque no sé si en igual medida: ser un «abuelo Cebolleta» o «tener más hambre que Carpanta» son expresiones que, incluso hoy, pueden escucharse en la calle.

Pero lo interesante es ver cómo, sobre todo en el caso de Bruguera, una cierta crítica social en forma de sátira se introducía en las páginas de unas revistas que tenían una amplia difusión. A través de la burla que se hacía de instituciones sociales como la familia en su conjunto, el padre, la suegra, el jefe o el policía, se podían cuestionar, muy someramente, los pilares morales e ideológicos del franquismo.

Al mismo tiempo, era posible criticar las condiciones de vida de la época: no puede pasarse por alto la existencia de un personaje como Carpanta — creado, además, por un autor como Escobar, combatiente republicano que pasó por la cárcel tras la Guerra Civil—, que 


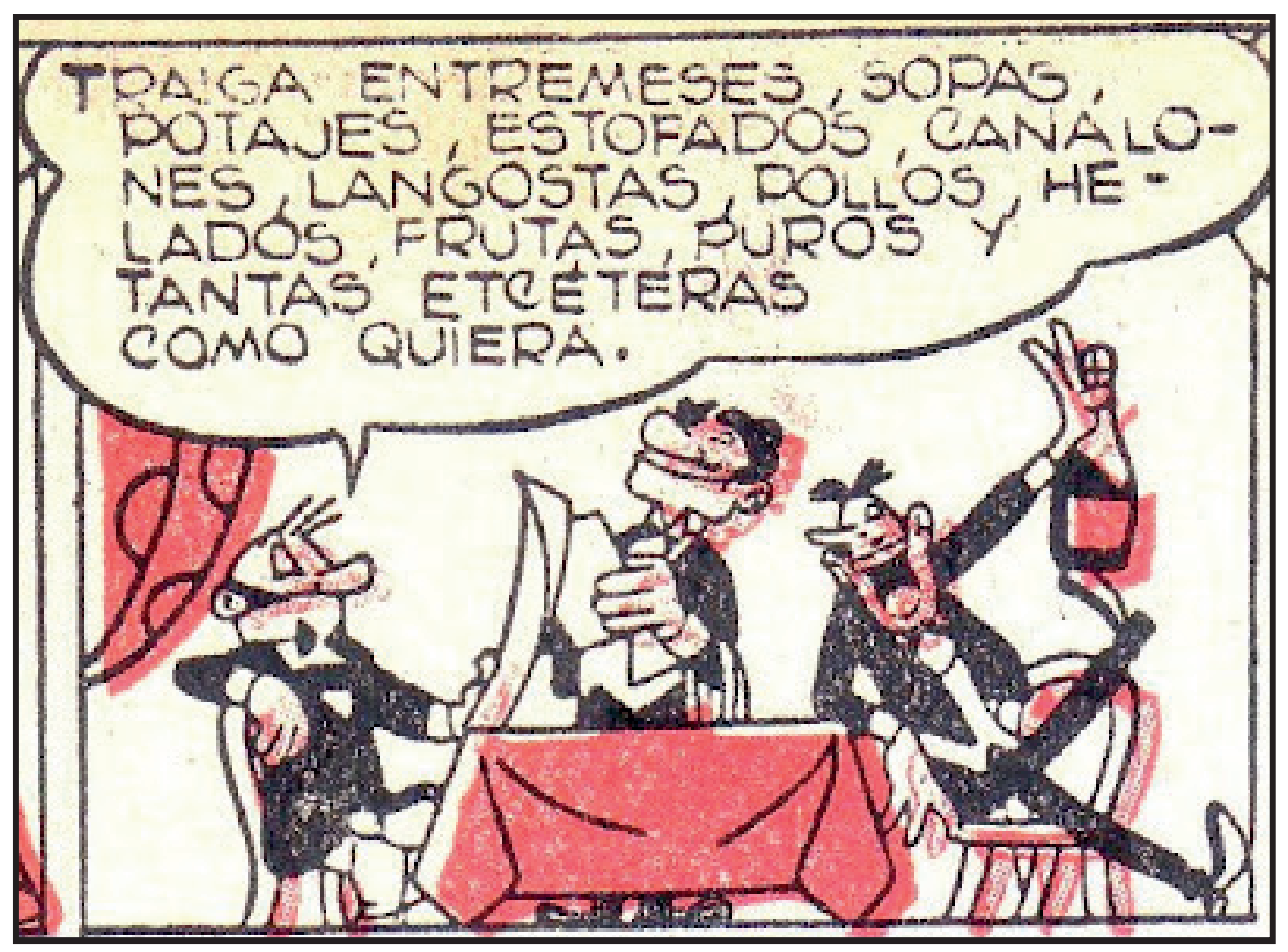

FIG. 5. Una viñeta temprana de Carpanta, la creación de Josep Escobar para Bruguera en 1947.

exponía el hambre que se sufría en la posguerra y la miseria de alguien que no tenía ni hogar, en una época en la que la consigna oficial era que «en la España de Franco nadie pasa hambre».

Yo suscribo la teoría que expone que esa crítica era posible porque las autoridades no prestaban la suficiente atención a un producto situado en lo más bajo de la cadena cultural, un entretenimiento barato para niños que no merecía el tiempo de los censores. Sin embargo, eso va a terminar con la creación, en 1952, de una Junta Asesora de Prensa Infantil, que promulgó las primeras normas específicas para este tipo de publicaciones.

El efecto de estas normas fue inmediato y hubo de rebajarse el nivel de violencia y humor negro de las historietas, al tiempo que se dulcificaba la sátira y se impedía que se cuestionara el statu quo, las instituciones o las figuras de autoridad, ni siquiera con fines humorísticos. Un ejemplo recurrente del impacto de estas normas es la desaparición del título Doña Tula suegra, de Escobar, por la imagen negativa que daba de la figura de la suegra y el ambiente familiar conflictivo que retrataba.

Antes de avanzar un poco en el tiempo y entrar a valorar la aparición de autores como Oesterheld o Breccia, me gustaría preguntaros si existía en Argentina una legislación específica que regulara los contenidos, al margen de esas cuestiones ideológicas que ya habéis explicado. 
Amadeo Gandolfo: La realidad es que en Argentina nunca existió un código o junta de censura explícita para las publicaciones impresas. A diferencia del cine, que tuvo durante gran parte de su historia la figura del censor como elemento siempre a tener en cuenta (siendo Miguel Paulino Tato, censor de 1974 a 1980, su máximo y más triste exponente), el material impreso más bien navegaba una tierra gris en donde no se lo regulaba explícitamente pero siempre existían mecanismos para controlar lo indeseable. La cuestión de la falta de código tenía que ver, creo yo, con la defensa, al menos de nombre, del valor de la libertad de prensa, tan caro para el liberalismo argentino.

Durante el peronismo las publicaciones se controlaban a través de la provisión de papel, que se importaba por completo y cuya distribución se encontraba en manos del Ministerio de Comercio. A través del retaceo de este material vital se llegó al cierre, por ejemplo, de la revista de humor gráfico Cascabel, opositora al peronismo. También siguió adelante una política de expropiación de editoriales y medios, pero no llegó a la historieta un poco, supongo yo, por lo que vos decís, Gerardo: era un eslabón muy pequeño e insignificante dentro de los medios existentes.

Por otro lado, también se encuadró muy rápidamente y no realizó verdaderas protestas durante el peronismo. Probablemente la inmensa producción impresa y las posibilidades de trabajo compensaban cierta falta de libertad de prensa. Y también los personajes se adaptaban bien a un mundo apolítico.

En el período 1955 a 1976 la censura es de una gran arbitrariedad. Se cierran revistas y suplementos con las excusas más variadas, pero en general con un principio de respeto a la autoridad. A medida que nos acercamos a la fecha del golpe, la excusa comienza a ser más que nunca el control del comunismo, «la subversión» y por supuesto el número de clausuras crece. En cuanto a humor gráfico, los casos notorios tienen motivos más bien pacatos, una preocupación por la moral. A Tía Vicenta la cierran por burlarse del bigote del general Onganía, comparándolo con una morsa; a Satiricón, por su alto contenido sexual y por las burlas a Isabel Martínez de Perón.

Hay casos menos notorios, como el de 4 Patas, una revista creada en 1960 por ex colaboradores de Tía Vicenta, que era observada por la oficina de Coordinación Federal de la Policía Federal, uno de los órganos de represión política de la fuerza, quienes finalmente le informan que deben cerrar por izquierdistas. Y a estos casos más sonados se pueden agregar miles de instancias micro de autocensura o control interno de las publicaciones. Todo esto mientras se intentaba sostener un discurso de libertad de expresión.

Eso al menos en el caso de las publicaciones de humor político, las más vulnerables. En cuanto a las publicaciones infantiles, de aventuras y masivas, lo que fue quedando de la industria, creo que no estaban tan sujetas a una censura sutil y sorpresiva, básicamente porque tanto no se metían en política. Hay casos puntuales, como la biografía del Che de Oesterheld y los Breccia, pero son excepciones. Seguro Pablo pueda completar esto mejor que yo. 


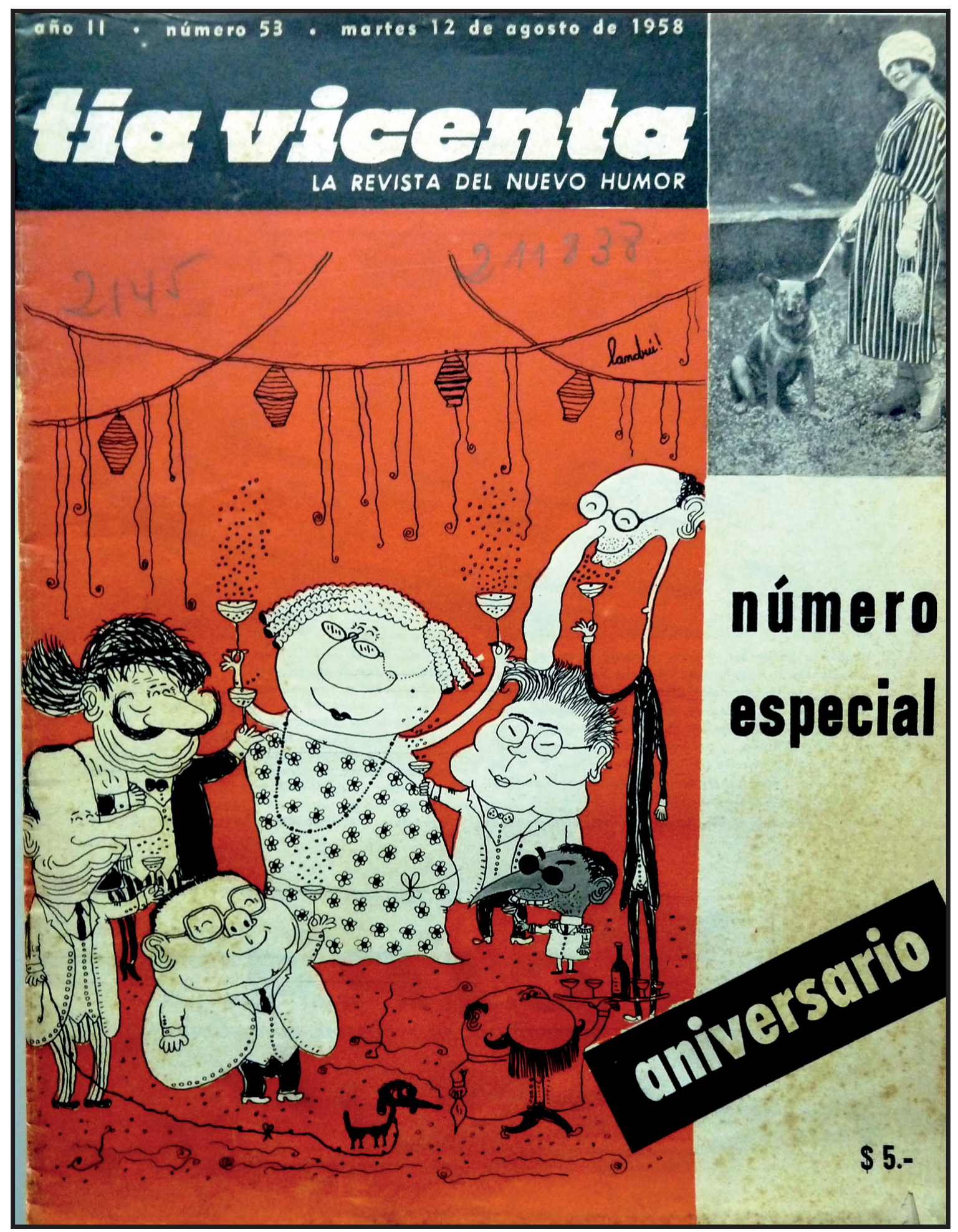

FIG. 6. Tía Vicenta n. 53 (Landrú, agosto de 1958) 
Pablo Turnes: Lo de Vida del Che Guevara es un gran malentendido. Nunca la «censuraron», lo que pasó fue una redada del ejército en la editorial de Jorge Álvarez donde destruyeron todo. Entre ese todo, estaban los ejemplares de la historieta, que en principio había vendido bastante bien, aunque es cierto que un editorial del diario La Nación había advertido sobre la peligrosidad de hacer una historieta semejante.

Hay algo de eso que mencionabas, Gerardo, sobre volar por debajo de los «radares culturales», como dijo Art Spiegelman. Lo curioso es que eso, que en otros casos se denuncia como desprecio cultural y de clase, en el caso argentino sirvió para que la historieta pudiera pasar por periodos de censura y persecución ideológica muy crudas relativamente inalterada.

El ejemplo más trágico y patético es el de Oesterheld: su desaparición tuvo que ver con su posición política y un compromiso férreo sostenido con Montoneros, no con su tarea como guionista de historieta. Al contrario, han llegado testimonios de otros prisioneros que compartieron con él centros de detención y tortura que cuentan cómo un oficial, si no me equivoco, le expresaba su admiración y hasta le encargó con entusiasmo una historieta sobre la historia del ejército argentino. Ni siquiera en la peor de las situaciones se consideraba su oficio como algo peligroso. Oesterheld tuvo que seguir escribiendo hasta literalmente el final, es la hipérbole de la lógica industrial: producir hasta la muerte.

La historieta de los setenta está plagada de alegorías y metáforas, cuando las leemos hoy encontramos eso muy evidente. No es necesariamente malo, el problema es que después se haya vuelto hegemónico ese tipo de historietas (estilo realista, géneros narrativos con la ciencia ficción como objeto privilegiado, bajada de línea algo pesimista, irónica). Eso terminó en una fórmula vacía y repetitiva, que no sabía hablarles a nuevos públicos.

Originalmente no había otra opción desde el punto de vista de los historietistas, porque vivían en una sociedad amedrentada por la violencia estatal, pero además por un código de autocensura no siempre explicitado pero sí firme y generalizado. Los medios de comunicación no solo fueron cómplices, fueron parte constitutiva de los períodos dictatoriales y de la represión antisocial en general.

En ese marco, los autores hacían cosas incluso sin proponérselas, que un público tendía a leer en clave de «decodificación»: un gran secreto compartido y prohibido traficado en historietas. La politización a veces era más evidente y otras no, siempre relativizando la «intención» de los historietistas.

Yo encuentro básicamente dos modelos coexistentes: uno, el de Horacio Altuna y Carlos Trillo, con ese costumbrismo algo delirante, futurista y apocalíptico.El otro sería el de Alberto Breccia, que gira sobre sí mismo en las búsquedas experimentales. Es todo lo opuesto: el realismo se deforma, todo está muy distorsionado por momentos, es denso y oscuro, casi que asusta a los lectores. Comparen una mujer dibujada por Breccia y otra dibujada por Altuna y entenderán lo que les digo. Los objetivos eran bien diferentes. 


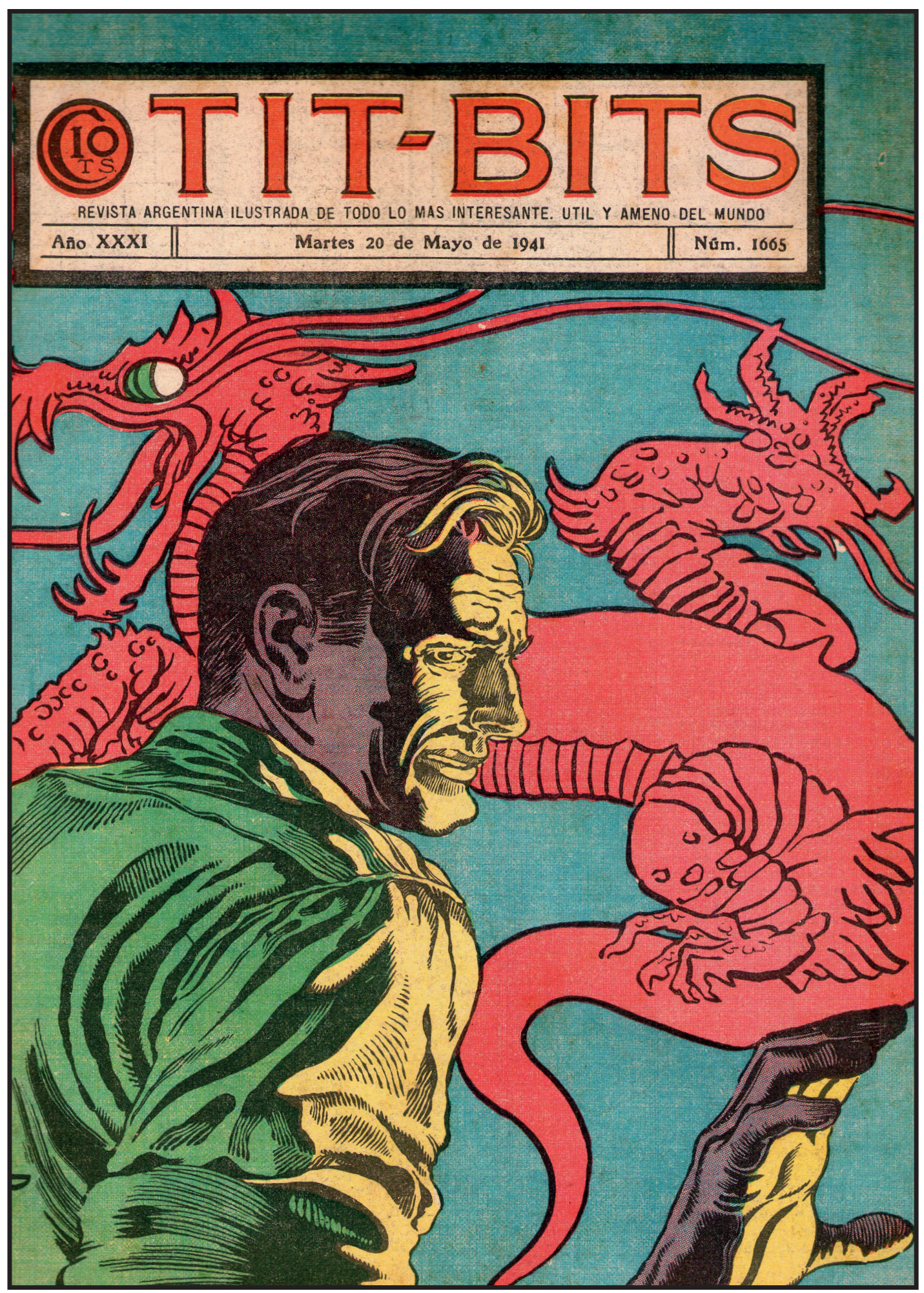

FIG. 7. Cubierta de Alberto Breccia para la revista Tit-Bits (1941). 


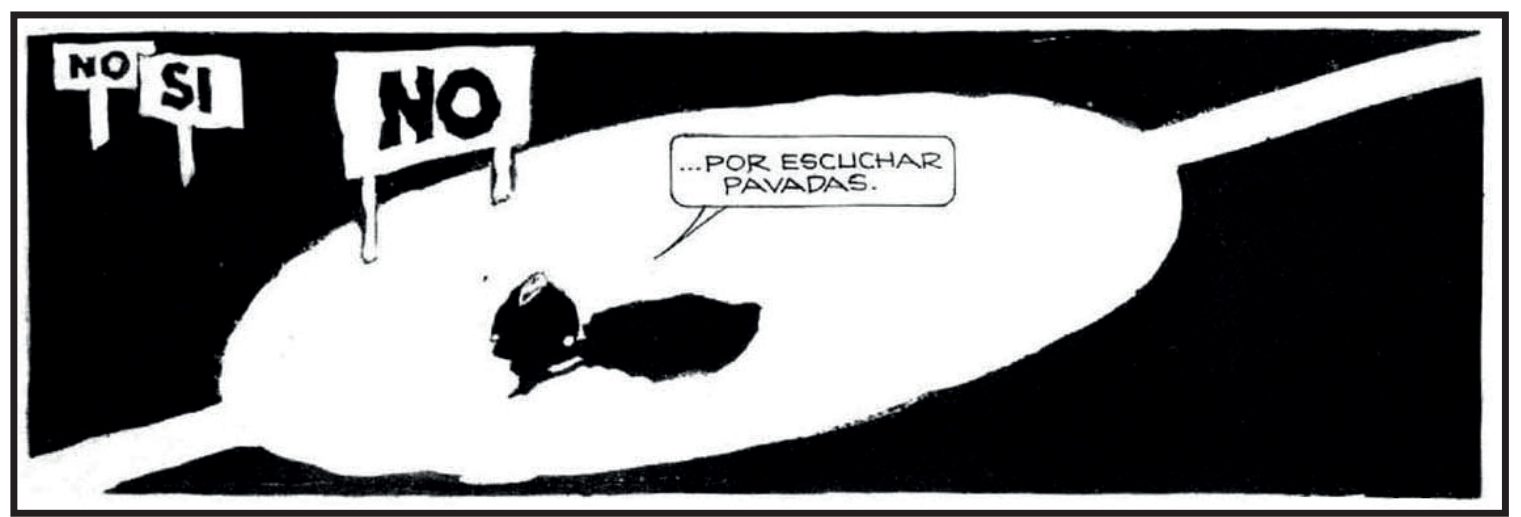

FIG. 8. Breccia, A. y Trillo, C. «Buscavidas.

La vida es un bolero absurdo», en SuperHum ${ }^{\circledR}$

n. ${ }^{\circ}$ 14, (febrero de 1982) Ediciones de la Urraca.

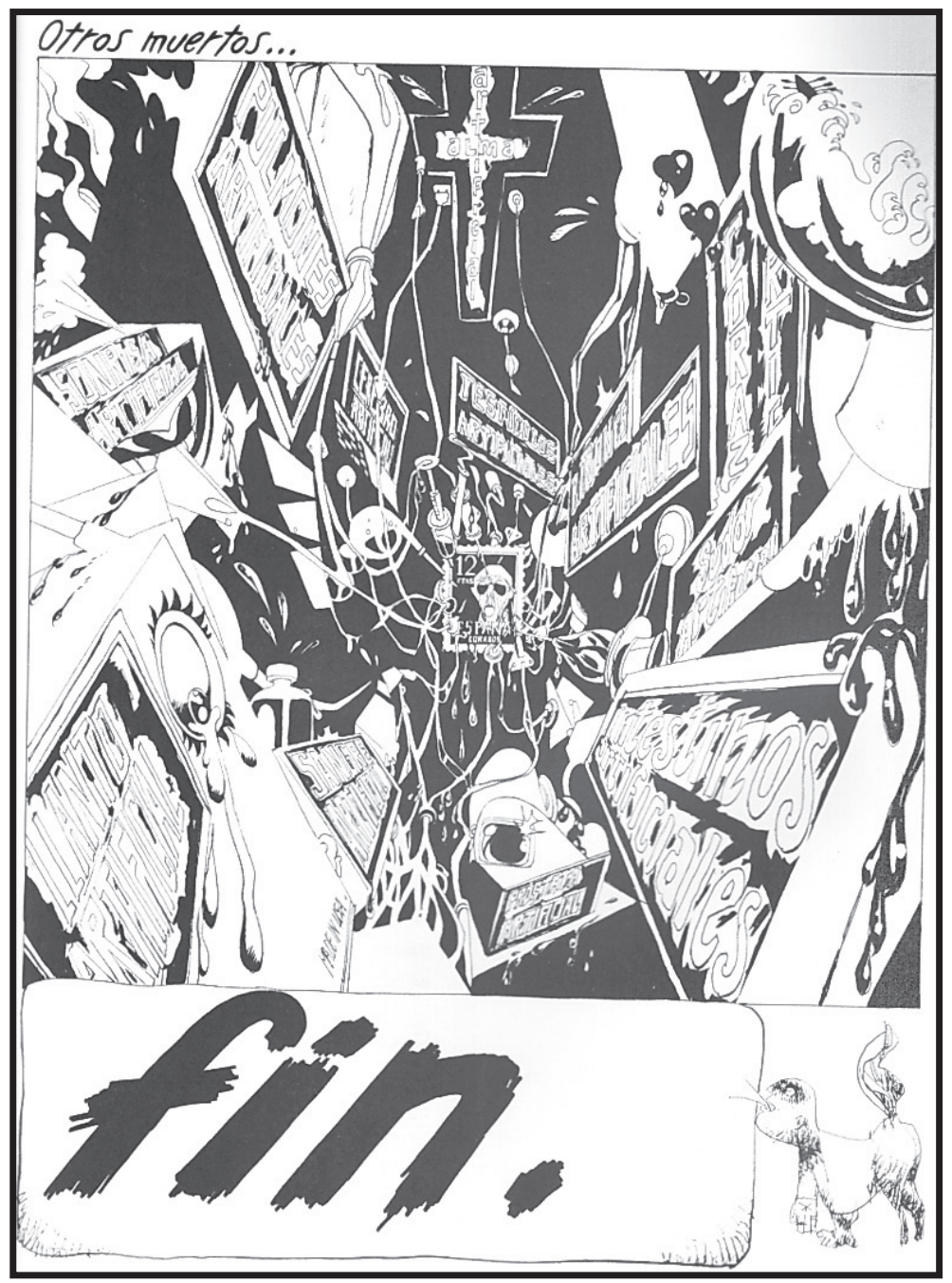

FIG. 9. Muñoz, J. y Sampayo, C. Alack Sinner:

Constancio y Manolo (1977). 
Yo creo que hay que mirar Buscavidas, es una de las obras más importantes sobre la dictadura y, sobre todo, contra la dictadura. A tal punto que el guionista, que también era Trillo, tampoco entendía del todo qué era lo que Breccia estaba haciendo con sus guiones.

Es una codificación tan hermética que se vuelve surrealista. Ahí hay una cuestión mucho más política que con lo del Che, que fue un encargo donde Breccia aprovechó para experimentar (aunque lo negara), porque realmente no le importaba la historieta. Buscavidas es la transformación del lenguaje historietístico en una representación de la comunicación en una sociedad silenciada, temerosa y cobarde.

Por cierto, buena parte de estas cosas fueron publicadas solo en Europa y apenas en parte en la Argentina de esos años. Nunca hubo un problema con las autoridades locales. En España censuraron la última página de una historieta de Alack Sinner, "Constancio y Manolo», porque aparecía una estampilla con la cara de Franco ya muerto, todavía chupando transfusiones de sangre de España. En Argentina, que yo sepa, eso nunca pasó durante la dictadura.

Gerardo Vilches: Todo lo que comentáis sobre la censura y los mensajes políticos más o menos conscientes y más o menos codificados me hacen pensar mucho sobre por qué en España las cosas fueron tan diferentes. Más allá de lo obvio, el hecho de que los autores debían trabajar en una dictadura, creo que tuvo más que ver con que todo el medio estaba controlado por editoriales y el trabajo era siempre de encargo. No soy capaz de encontrar ningún ejemplo tan temprano de cómic con un mensaje como El Eternauta en el caso español. Pero tampoco fue posible la aparición de un cómic orientado a un público más maduro, y creo que esto es clave porque ambas cuestiones están relacionadas, en mi opinión.

En España, la generación que podría haber hecho un cómic equivalente a Mort Cinder o el citado El Eternauta no encontró dónde hacerlo. Alguien como Víctor Mora, con ideas políticas de izquierda, solo podía incluir en sus guiones difusas y remotas alusiones a caciques y caudillos que héroes como el Capitán Trueno derrocaban en nombre de la libertad... pero en una ficticia Edad Media que, estoy seguro, no constituyó nunca una alegoría que el público mayoritario entendiera como tal. Hay que comprender también que el tebeo español se infantilizó aún más tras la aprobación de la ley que comentaba anteriormente, hasta el punto de que el material que se reeditaba - una práctica constante - era intervenido sin ningún tipo de pudor: las faldas de las mujeres se alargaban, y se borraban armas blancas de las manos de los guerreros. Vicent Sanchis ha documentado esta práctica ampliamente. ${ }^{2}$

En ese contexto, no había una demanda por parte del público, ni una intención por parte de las editoriales de ofrecer un material algo más adulto donde una nueva generación de autores pudieran desarrollar algo parecido al primer cómic adulto que estaba surgiendo en el resto de Europa y Argentina. La salida era dibujar historietas de aventura para niños, historias de fantasía y costumbrismo naif para niñas, o el humor. Pero además había otra cuestión fundamental: la económica. Vivir del cómic en España en los años cincuenta, aunque hoy algunos

${ }^{2}$ SAnchis, V. Tebeos mutilados. La censura franquista contra la editorial Bruguera. Barcelona, Ediciones B, 2010. 
nostálgicos aseguren lo contrario, era bastante difícil. Las tarifas no eran muy altas y solo si el dibujante tenía mucha demanda podía prosperar, a costa de trabajar muy duramente. ${ }^{3}$

De modo que, durante esa década, muchos dibujantes comenzaron a trabajar para mercados extranjeros por encargo, a través de la mediación de agencias artísticas, la más conocida e importante de las cuales fue Selecciones Ilustradas, fundada en 1956. Fue una iniciativa de Josep Toutain, que había empezado a trabajar como dibujante años antes para el mercado francés. En una época en la que las comunicaciones no estaban aún tan desarrolladas como hoy, Toutain se dio cuenta de que era preciso un intermediario entre los dibujantes españoles y las editoriales que demandaban una cantidad ingente de material.

Los dibujantes que comenzaron a trabajar para Toutain recibían guiones de escritores radicados en el país de origen de la editorial cliente, convenientemente traducidos, y realizaban su trabajo a destajo. Había clientes de toda Europa. En aquellos primeros años de actividad, en ningún momento, que yo sepa, se planteó siquiera la posibilidad de producir material directamente para el mercado español. Supongo que al margen de las restricciones censoras, no había mercado ni posibilidades económicas para una revista con ese tipo de cómic. En ese nuevo modelo industrial trabajaron autores como Jordi Longarón, Carlos Freixas o Enrique Badía Romero. Dicen algunos que los dibujantes españoles eran los más apreciados por su calidad. No voy a negarlo, pues calidad tenían, pero sí quiero añadir un punto de realismo: también eran más baratos. Y eso se vio aún más claramente cuando Selecciones Ilustradas comenzó a surtir de material a la estadounidense Warren a partir de 1970.

Sea como fuere, lo cierto es que aquella generación de autores de escuela realista, especializados en géneros que permitían esa codificación de la que hablaba Pablo, desapareció del mercado español casi por completo. Tardaron mucho en poder hacer obra propia que vender al extranjero, y más aún en ver esa misma obra publicada en España, porque hasta mediados de los setenta no empezaron a aparecer revistas que dieran cabida a esos cómics.

Es el caso de las primeras obras de Carlos Giménez. Delta 99 o Dani Futuro fueron concebidas primero para vender al mercado extranjero. La primera de ellas apareció en España en 1968, orientada a un público adulto. Se trataba de una historia de ciencia ficción, lo más parecido a esa metáfora encriptada en los mecanismos de género, pero tampoco estamos hablando de algo con una excesiva intención política: seguía siendo, en mi opinión, principalmente escapismo. El guion era de Jesús Flores Thies, y tras diez episodios pasó a manos de otros escritores y dibujantes. En cambio, historias como Hom - una adaptación de una novela de Brian Aldiss - y Koolau el leproso — una adaptación de un relato de London-, ambas ya en solitario, sí responden claramente a una intención crítica y política en un contexto de ciencia ficción... pero datan, respectivamente, de 1975 y 1978.

\footnotetext{
${ }_{3}$ «Los dibujantes no podían exigir derechos [...]; firmaban unos recibos en los que cedían la propiedad de su obra a los editores, cobraban una escasa remuneración por viñeta y no percibían royalties». En Guiral, A. (coord.). Del tebeo al manga. Una historia de los cómics. Tomo 9: Revistas de aventuras y de cómic para adultos. Barcelona, Panini Cómics, 2007, pp. 97-98.
} 


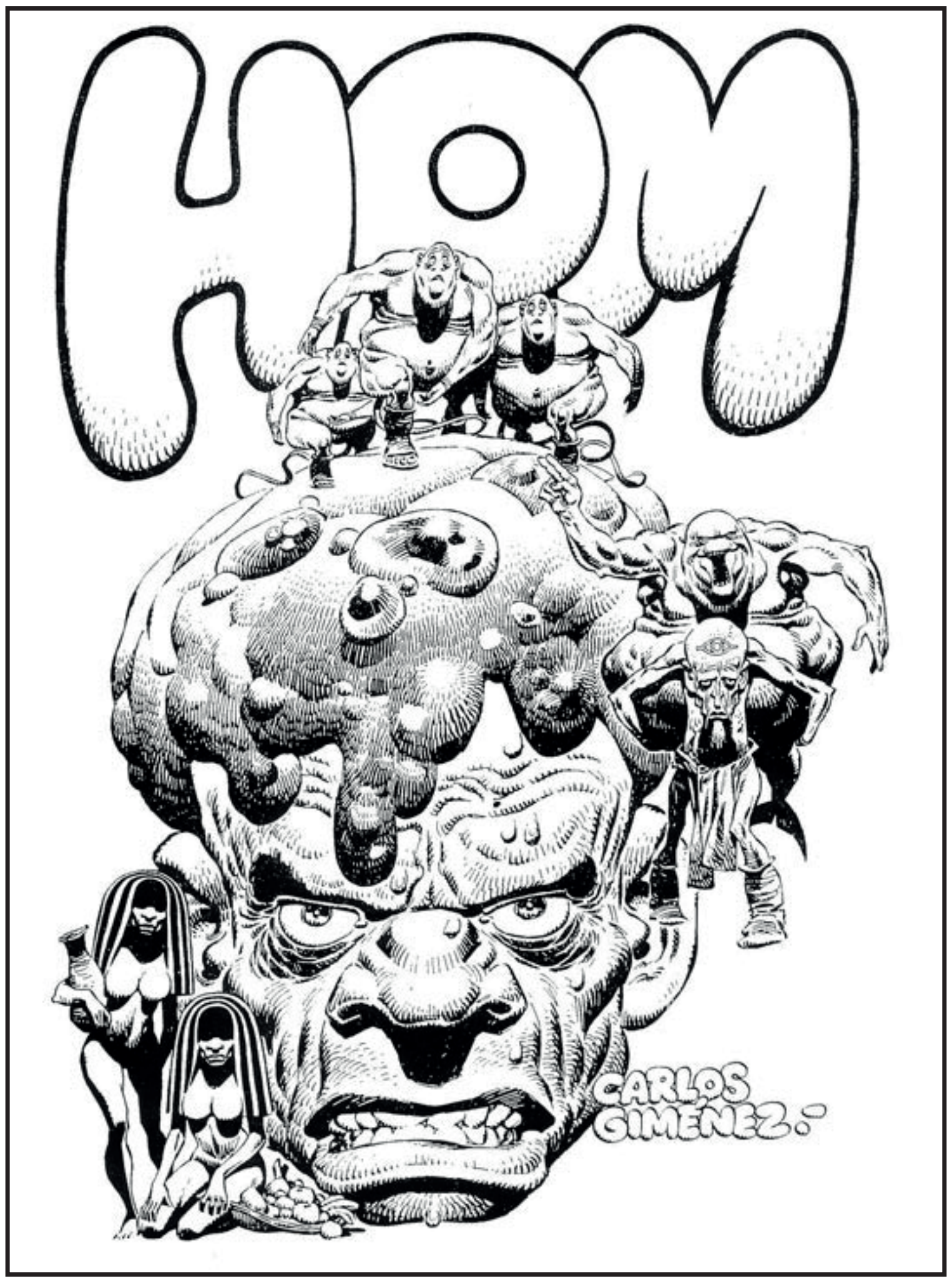

FIG. 10. Giménez, C. Hom. Barcelones, Ediciones Amaika, 1977. 
Podríamos aducir al socorrido retraso que el franquismo había supuesto para la cultura española, pero me gustaría profundizar en esto porque estoy seguro de que el fenómeno tiene una explicación más compleja: ¿por qué creéis que en Argentina, al contrario que en España, sí apareció una generación encabezada por Héctor G. Oesterheld y Breccia que, partiendo - corregidme si me equivoco- de la influencia del cómic europeo, fue capaz de producir obras para adultos tan notorias como Mort Cinder o El Eternauta? Y no solo eso, sino que en lugar de venderlas a un mercado extranjero, eran primero publicadas en el argentino y luego vendidas fuera.

Y al hilo de esto, otra cuestión que creo central para entender las diferencias en este periodo entre ambos países: ¿cómo fue posible la fundación de una revista como Hora Cero? Porque ese concepto de revista autogestionada por su autores, que eran editores al tiempo, aquí era inconcebible. Existió un intento, Tío Vivo (1957), pero se saldó con un fracaso y con la vuelta de los autores a la editorial Bruguera.

Pablo Turnes: Es una buena pregunta... Yo creo que esa experiencia fue excepcional para Argentina también. Por empezar, fue sumamente breve, duró poco más de dos años entre 1957 y 1959, porque para 1960 la cosa ya no marchaba y coincidió con una baja generalizada de la industria editorial de revistas. Esto se sumaba a malos manejos que hicieron que los dibujantes se distanciaran de Oesterheld, siendo el caso de Pratt el más significativo.

Todos venían de trabajar en la industria editorial que era bien jerárquica y sistematizada, pero al mismo tiempo proveía de bastante margen de maniobra para que en algún punto los autores pudieran desarrollarse. Los sueldos en general no eran gran cosa, y había que trabajar mucho, pero al mismo tiempo proveían cierta estabilidad sabiendo que uno podía contar con un ingreso fijo y ciertos beneficios laborales si mantenía una cuota de producción.

La Editorial Frontera fue posible por la experiencia acumulada por todos los que la formaron y sostuvieron esos breves años, sumando la libertad creativa y por supuesto, la necesidad de ganar más y mejor. Era un objetivo ambicioso, sobre todo para la lógica del sistema industrial: trabajar sin un editor que pusiera los límites, sin patrones. ${ }^{4}$

Lo otro es, obviamente, la diferencia con el contexto político que implicaba tener una dictadura como la de Franco y sus características muy particulares, además del contexto económico español de posguerra. Si bien en Argentina en ese momento había un gobierno de facto, la Revolución Libertadora que había derrocado a Perón, la industria cultural no estaba directamente atada al devenir político. La cuestión de la censura corría más por parte de un editor particular (lo de las polleras también lo hacía Quinterno), que por parte del Estado.

Afectó más, en todo caso, la idea de una economía de libre mercado que hizo que no se pudiera competir con las importaciones mexicanas, por ejemplo. Pero hasta entonces, la

${ }^{4}$ Laura Vazquez ha tratado bien esas cuestiones en su libro El oficio de las viñetas. La industria de la bistorieta argentina, Buenos Aires, Paidós, 2010. 


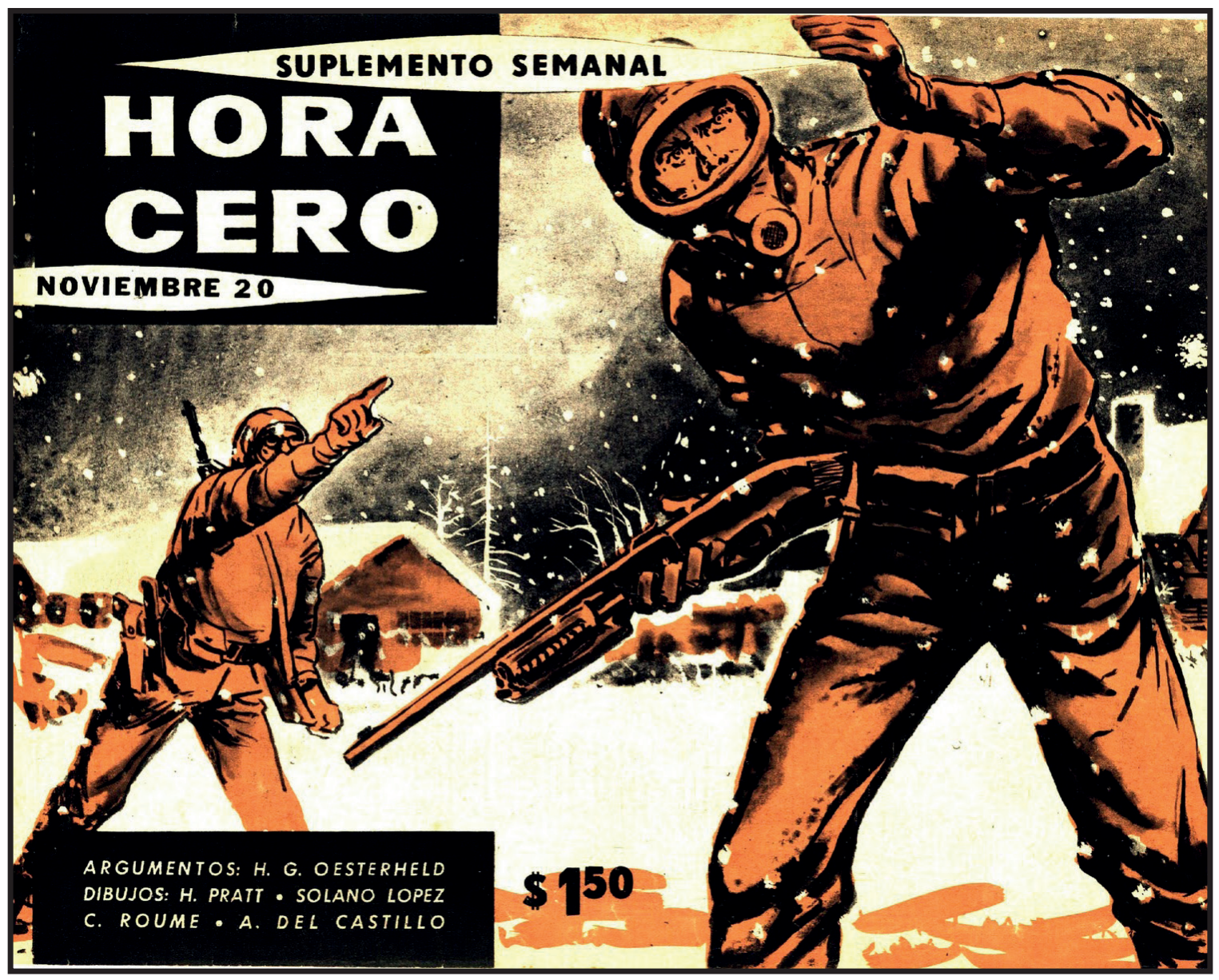

FIG. 11. Cubierta de Hora Cero, obra de Francisco Solano López (1957).

bonanza económica había sido notable, hasta el punto que Argentina ayudaba a España y a Japón, entre otros, enviando alimentos y ropa.

Lo curioso es que con el fin de esa experiencia y la crisis de la industria de la historieta a principios de los sesenta la estrategia que encuentran Oesterheld y Pratt es vender ese mismo material al exterior, cosa que antes no pesaba tanto, y en todo caso era para el mercado latinoamericano.

Pratt, de hecho, fue el que hizo la conexión a través de una agencia italiana que se llamaba Eurostudio, de los hermanos D'Ami, con la editorial Fleetway inglesa. Ahí hay un punto de contacto con lo que pasa con los dibujantes españoles. Y por razones similares: había una tradición gráfica que no existía a ese nivel en Inglaterra, y la diferencia de monedas hacía que los trabajadores fueran más baratos. Yo creo que, de alguna manera, esa industria del entretenimiento tan básica como era la inglesa da indicios de lo que vendrá: la tercerización globalizada, el capitalismo tal como lo conocemos hoy. Habría que investigar mejor esta cuestión, puede ser algo interesante. 
Desde principios de los sesenta hasta principios de los setenta, Inglaterra fue el destino de los dibujantes argentinos que querían hacer una diferencia económica manteniéndose en un ritmo de producción industrial. Al menos dos generaciones trabajaron para la Fleetway: la de Breccia-Pratt-Solano López y la de José Muñoz y Oscar Zárate, más jóvenes. Después la cosa derivó para Italia, con personajes como Marcelo Ravoni y las revistas como Linus, con el boom de la historieta de autor.

Una aclaración: muchas de las historietas «decodificables» eran primeramente editadas en Europa y después en Argentina, y en muchos casos se conocieron recién tiempo después, cuando la dictadura había terminado. De hecho, hay cosas que se han publicado en la última década que estaban o bien inéditas, o bien nunca habían sido reeditadas como compilaciones en formato libro.

Amadeo Gandolfo: Coincido con lo que dijo Pablo: fue un experimento muy corto el de Frontera, en gran medida justamente por la inexperiencia de Oesterheld a la hora de montar una editorial. Es raro eso, porque muchos de los más grandes editores argentinos fueron dibujantes e historietistas, pero también algunos produjeron grandes fracasos de la historieta argentina. Es algo que se comprueba en Frontera, pero también se ve muy claramente en los noventa con la crisis definitiva de un modelo basado en la revista. Creo que para ser un buen editor hacían falta algunas características que los artistas (dibujantes y guionistas) no tenían o si tenían los hacían inclinarse peligrosamente hacía un modelo de editor tiránico y malvado del cual justamente querían escapar. La factoría Quinterno era un lugar seguro donde trabajar pero también era un espacio con férreas reglas y manías de su creador que coartaban la creatividad.

Esa especie de lucha de poder entre los editores-artistas y los artistas «puros» se observa en las esquirlas del cierre de Frontera. Por un lado, tenés a Oesterheld, en la famosa entrevista que les concede a Trillo y Saccomano (y que es publicada en 1980 en el libro Historia de la Historieta Argentina, mientras Oesterheld se encontraba desaparecido) con cierto resentimiento diciendo que el guionista es «el hombre de la relación» frente al dibujante y también diciendo que Frontera tenía los mejores dibujantes porque se les pagaba más, precios equiparables a los de Europa, y que cuando se dejó de poder pagar eso los dibujantes lo desertaron. O sea, yendo en contra de la idea de Frontera como una editorial autogestionada en pie de igualdad entre todos sus participantes y colocándose a sí mismo en un lugar central que, además, es traicionado.

En segundo lugar, tenés a Pratt llevando al Sargento Kirk a Italia y vendiendo las tiras a publicaciones sin mencionar el nombre de Oesterheld, embolsándose los beneficios (dando lugar, además, a la desafortunada coincidencia del borramiento autoral de un autor efectivamente desaparecido). O sea que todo estaba muy lejos de ser color de rosa.

Con respecto a lo que preguntás acerca de por qué se dio esa generación de artistas que pudieron realizar ese tipo de obras, la verdad es que no tengo una respuesta precisa. Creo que, en parte, tiene que ver, en primer lugar, con el entusiasmo propio de una aventura como 


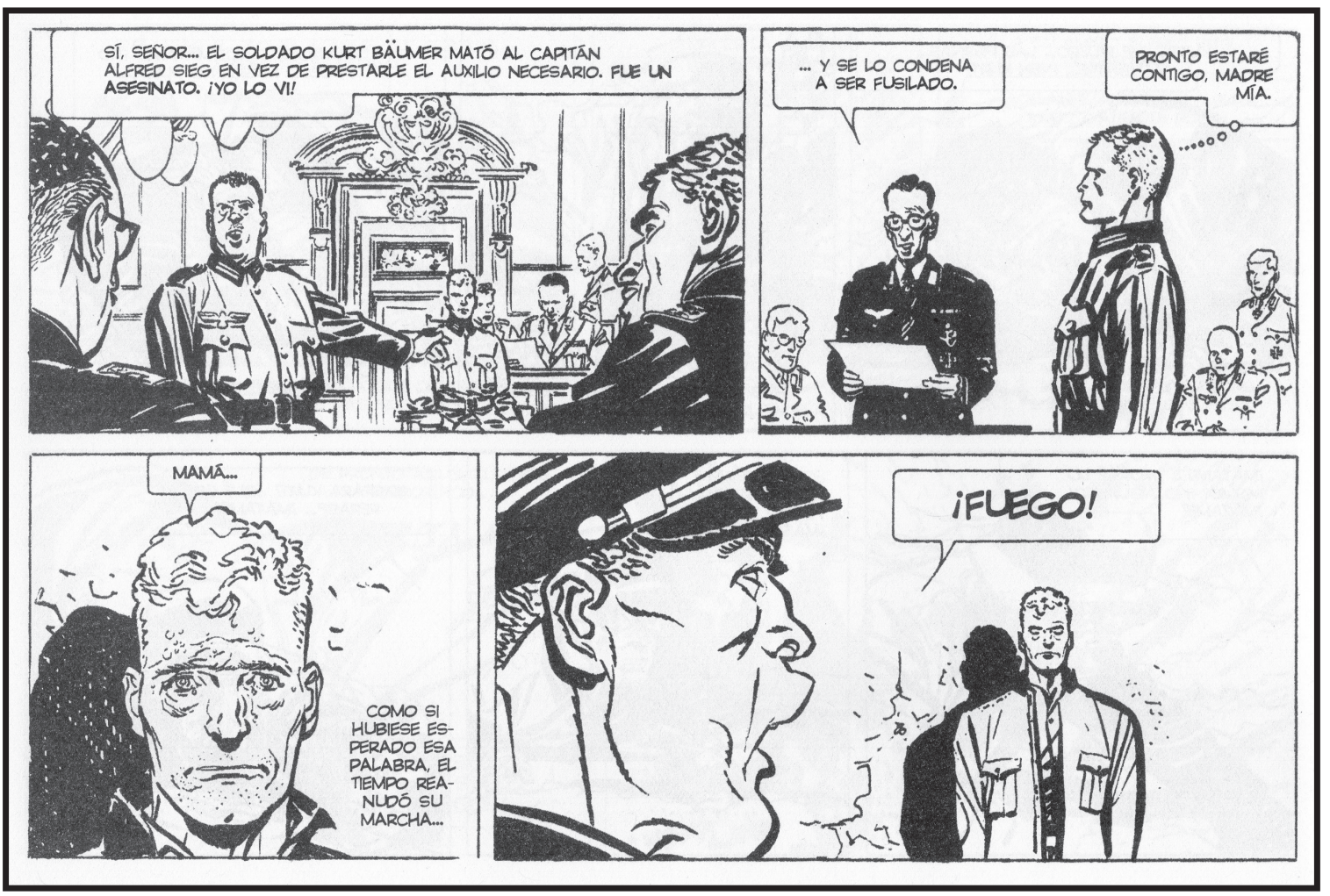

FIG. 12. Breccia, A., Oesterheld, H. G. «Ernie Pike. La ejecución», en Hora Cero n. ${ }^{\circ} 25$ (mayo de 1959).

Frontera y, luego, con una especie de sensación de que «no hay nada que perder», especialmente en el caso de Breccia, quien, como bien destaca siempre Pablo, hizo Mort Cinder como una especie de despedida del cómic.

También creo que, quizás, durante los sesenta había una percepción diferente de los artistas de historieta que en España. Si bien no dejaron de ser considerados como trabajadores culturales de segunda clase, sí había mucha imbricación entre lo que producían y el «sentir social», como mencioné más arriba haciendo referencia a los nombres de personajes humorísticos. Y durante los sesenta la historieta argentina es arrastrada por la modernización generalizada que acomete al país.

En eso tuvo mucho que ver Oscar Masotta con su labor como gestor y crítico, pero también es parte de un proceso más general que hace que la historieta sea vista como algo más que mero entretenimiento infantil, algo «moderno», "pop», e inclusive capaz de meter significaciones políticas en su tejido. A esto contribuyen la Bienal de la Historieta en el Di Tella, la revista Literatura Dibujada, pero también la publicación en Europa de Mort Cinder y la consagración de Pratt con el Corto Maltés.

Y creo, como Pablo, que la situación económica del país también tiene mucho que ver. $\mathrm{Du}-$ rante el peronismo la bonanza fue muy grande, y eso permitió el establecimiento de edito- 
riales y de una cierta industria cultural y una carrera de dibujante, algo que en una España devastada por las consecuencias de la Guerra Civil era mucho más difícil.

Durante los sesenta, si bien la economía argentina ya no tenía los extraordinarios beneficios de la época de posguerra, todavía contaba con una distribución del ingreso muy pareja entre trabajadores y capital (lo cual generaba más consumo y demanda) y un tejido social que privilegiaba la innovación, y en donde la clase media y los trabajadores tenían muy metida en la cabeza la idea de que solo hacía falta un empujoncito para que Argentina se introdujera entre las grandes potencias mundiales. Por ello el desarrollismo y la modernización, en principio económica e industrial, pero rápidamente derramada hacia lo cultural, fueron la ideología de base de la Argentina de los sesenta.

En esto yo querría hacer una observación con respecto a lo que mencionás, Gerardo, acerca de la influencia de la historieta europea en este fenómeno de maduración. Para mí son procesos que suceden simultáneamente y se retroalimentan. Los historietistas argentinos (o que pasaron por Argentina) tuvieron una influencia fundamental en los procesos europeos, y luego las novedades que se producen allá (Moebius, Crepax, etcétera.) fueron reintroducidas en Argentina y a su vez alimentaron los procesos locales.

Gerardo Vilches: Esa retroalimentación pienso que en España fue más complicada porque ese cómic de autor tardó en publicarse. Hay cierto desfase, aproximadamente de una década, que tiene que ver con las condiciones políticas y sociales. La cuestión económica, que ambos habéis mencionado, no influye tanto, en mi opinión, en el caso español. Es cierto que en los sesenta se experimenta lo que se denominó «desarrollismo», una política económica más aperturista, basada en el rearme industrial del país y en la explotación turística de sus costas, pero, aunque la industria editorial se benefició de ello, no apareció un cómic adulto autóctono.

Sí fue una época fructífera para el humor, especialmente en el caso del publicado por Bruguera, que tenía varias revistas en el mercado y domina la década. Pero, como os decía, otros autores tuvieron que trabajar para mercados extranjeros, de un modo similar al que habéis indicado. Por ejemplo, un pionero del cómic adulto español como Enric Sió publicó Mara íntegramente en 1968 en el mercado italiano.

Sin embargo, esto va a cambiar a partir de los años setenta, que es una década clave en España y que me gustaría que tratáramos en este debate. En 1975, con la muerte de Francisco Franco, da comienzo el periodo de transición política a la democracia, una fase en la que hay muchos claroscuros pero que, en lo que respecta al mercado editorial, trae un auténtico boom de publicaciones. Es un boom hasta cierto punto ilusorio, en tanto que no se cimienta en una base de lectores tan sólida como para justificar semejante número de revistas, pero que dio la oportunidad a muchos autores de publicar al fin directamente para el mercado español.

Estas revistas se beneficiaron, además, de una legislación más permisiva: la Ley 14/1966 de Prensa, conocida como «Ley Fraga» por el ministro que la impulsó, eliminaba la censura 
previa de las publicaciones, pero mantenía fuertes sanciones si se consideraba que incumplían alguno de sus artículos. Hablando con los editores y autores de la época, he podido comprobar hasta qué punto la aplicación de esta ley era arbitraria y caprichosa, lo cual no impidió que varias revistas satíricas sufrieran cierres de varios meses, como fue el caso de $E l$ Papus o Por Favor. En 1977, no obstante, se deroga el artículo 2 de dicha ley, que protegía la moral y las instituciones y que fue la excusa más empleada para castigar a estas revistas.

Antes de esa fecha, ya había aparecido la revista Star, en 1974. Se trató de una revista fundamental en el mercado español porque, con cierto retraso, se publicó comix underground de Robert Crumb o Gilbert Shelton, por ejemplo. Pero, además, fue una de las primeras ocasiones para ver el trabajo de la nueva generación de autores españoles: Max, Gallardo, Ceesepe... Poco después, Toutain, el responsable de Selecciones Ilustradas, comienza a publicar revistas antológicas de cómic adulto...

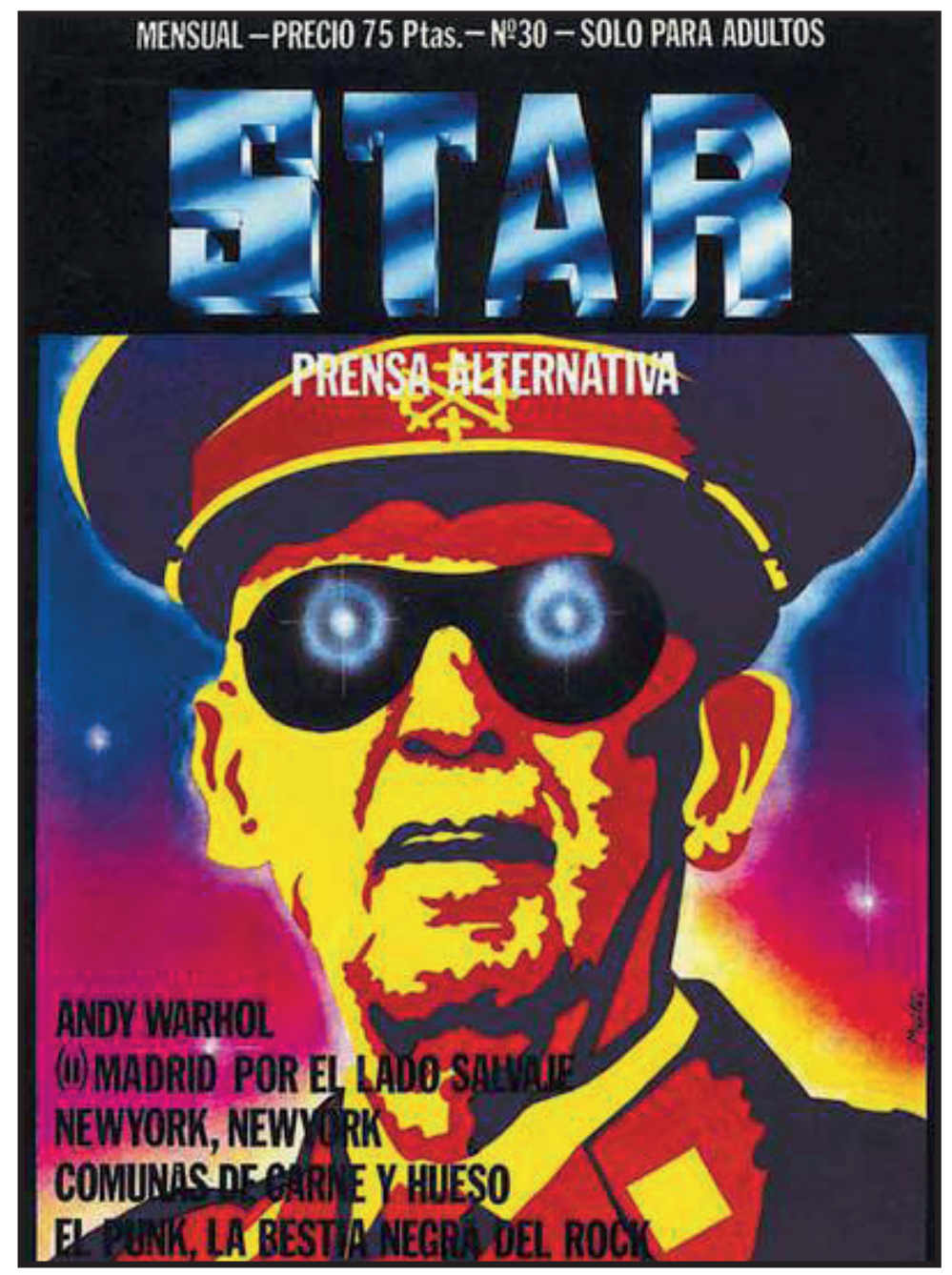

FIG. 13. Una de las cubiertas más conocidas de la revista Star, correspondiente a su número 30 (1977). 
Aunque, como os podéis imaginar, la definición dista mucho de lo que hoy consideramos como tal: hablamos de cómic de género, fantasía, ciencia ficción, terror, etcétera, que tiene unas dosis mayores de erotismo y violencia, aunque también ciertas reflexiones políticas o filosóficas, en consonancia con el cómic francés que se había empezado a hacer en los sesenta.

La precisión temporal es importante: tengo la impresión de que muchas tendencias y obras llegaron a España tarde, con aproximadamente una década de retraso, de modo que rápidamente les pasó por encima la siguiente generación. En muy poco tiempo, en revistas como Cimoc, Totem, Comix Internacional o 1984, editoriales como Nueva Frontera, Toutain y su más directo competidor, Norma Editorial, publicaron en España en forma seriada decenas de obras fundamentales para el cómic franco-belga y americano, así como también obra de producción propia y, muy importante, parte de la producción para el extranjero que los autores españoles en la nómina de Selecciones Ilustradas habían realizado.

Fue la época en la que empezamos a conocer realmente en España el trabajo de autores de prestigio internacional como Esteban Maroto o Pepe González, pero también es la época en la que la figura de Carlos Giménez se sitúa en el primer plano, gracias a Paracuellos, $B a-$ rrio o, ya en los ochenta, Los profesionales.

\section{Este debate continuará en el próximo número de CuCo, Cuadernos de cómic.}

